\title{
Colour of grapevine (Vitis vinifera L.) accessions influenced by the length of cold storage Grapevine berry colour measurement
}

\author{
E. SOMOGYI ${ }^{1}$, J. LÁZÁR ${ }^{2}$, P. BODOR ${ }^{1}$ and T. KASZAB ${ }^{3 *}$ (]
}

\footnotetext{
${ }^{1}$ Department of Viticulture, Institute of Viticulture and Enology, Faculty of Horticultural Sciences, Szent István University, Budapest, Hungary

${ }^{2}$ Research Institute for Viticulture and Oenology of the National Agricultural Research and Innovation Centre of Kecskemét, Kecskemét, Hungary

${ }^{3}$ Department of Measurements and Process Control, Institute of Biosystems Engineering and Process Control, Faculty of Food Science, Szent István University, Budapest, Hungary
}

\section{CONFERENCE FULL PAPER}

Received: August 14, 2020 • Accepted: September 25, 2020

Published online: November 18, 2020

(C) 2020 The Author(s)

\section{ABSTRACT}

Colour is one of the most important phenotypic characters of the table grape cultivars, which has high importance in the consumer's preference. This morphological trait is variable and not consistently uniform within a cultivar or even a bunch. Between harvest and consumption fruits are stored for several weeks which time is influencing the colour of the berry. In this study 10 grapevine accessions (Agaphante, KM98, Korai piros veltelini, Korona, Pinot gris, Pozsonyi, Ros de Minis, Tramini piros, T9, Zenit) were collected from the germplasm collection of the Research Institute for Viticulture and Oenology of the National Agricultural Research and Innovation Centre of Kecskemét. The samples were investigated by ColorLite Sph850 spectrophotometer. The colour of 30 berries per accessions were measured in 3 replicates per berry. The aim of this study was to evaluate the colour and the effect of cold storage. $L^{*}, a^{*}, b^{*}$ values of each accessions were evaluated after the sampling and until a visible reduction in the quality of the grapes, at most 4 weeks with 1-week intervals from the harvest. Results showed that there is a significant difference among the cultivars in the $\mathrm{L}^{*}, \mathrm{a}^{*}, \mathrm{~b}^{*}$ values. The length of cold storage also has a significant effect on the colour of the accessions as the values are changing in some cases of the 1-week storage period.

\footnotetext{
*Corresponding author. E-mail: kaszab.timea@szie.hu
} 


\section{KEYWORDS}

Vitis vinifera L., berry, colour, L*a*b*

\section{INTRODUCTION}

The consumers' preference is depending on the appearance not only in the case of table grape varieties but many horticultural crops. Numerous researches are dealing with this question. Although the colour of crops is a subjective factor, yet for the consumers this factor stands almost always on the first place of the many characteristics determining the appearance of the fruits and vegetables (López Camelo and Gómez, 2004). Jemison (2008) alludes the skin colour of potato tubers as the most important feature in the aspect of consumers' preference. For example, in Kenya the white coloured sweet corn is more favoured than the higher carotenoid containing yellow sweet corn (De Groote and Kimenju, 2008). In the case of bell peppers the green variants are the most marketable, while the red, yellow and orange cultivars take a minor part of the market (Frank, 2001). According to the research by Lopez Camelo and Gómez (2004) the most determinative characteristic of tomato cultivars is the colour. Cliff et al. (2002) found that the apples with red skin colour are the most merchantable, while the green ones are less pleasing for the consumers. The colour has such a high influence that in many cases green apples with better content values are less preferred (Hamadziripi et al., 2014). In the case of cherry cultivars, it can be said that the darker the skin colour the higher the number of consumers (Crisosto and Crisosto, 2003). The colour also has an accentuated place among the quality influencing factors of date cultivars (Ismail et al., 2001) and the consumers' choice about the edible flowers (Kelley et al., 2001).

Table grape cultivars possess many special features of quality. These refer mainly to the appearance of the fruit: attractiveness of the berries and the bunches, berry shape, and bunch compactness are the most important. Uniform colour of the berry or berries within the bunches is also not a negligible characteristic (Bényei and Lörincz, 2005). As regards colour, table and wine grape cultivars are usually divided into 3 groups: white, red, and blue. There are, nevertheless, a large number of shades materializing, for instance the green, greenish-yellow, yellowish-green, light yellow, even the amber berries are listed as white coloured cultivars. All shades of red, including the bluish-red, are listed into the red coloured cultivars. Blue coloured cultivars could be light reddish-blue, dark blue and black, as well (Kozma, 1968). The red colour is mainly due to anthocyanins (Liao et al., 1992; Mazza et al., 1995). Beside anthocyanins there are other colouring substances in grapevine such as $\beta$-carotene, different xanthophylls and chlorophyll-derived compounds which affect not only the colour, but also the flavour of the wine (Mendes-Pinto et al., 2005). The appearance of the berries is also influenced by the thickness of the wax layer (Csepregi and Zilai, 1955). From the consumers' aspect the uniform berry colour is highly important. For example, greenish spots create the impression of unripe fruit, furthermore, the fully ripe green berries are disliked, too. Russeting - which is a typical attribute of the white grapevine cultivars - could also have a negative effect on the estimation of the yield (Kozma, 1968).

Nowadays the descriptor list of the International Organisation of Wine and Vine (OIV, 2009) is used for the description of the grapevine accessions, in which the following 6 colours refer to the berry (OIV 225): greenish-yellow (Chasselas B), rosé (Chasselas Rosé Rs), red 
(Chasselas Rouge Rg), grey (Pinot gris), dark purplish-red (Cardinal Rg) and bluish-black (Pinot $\mathrm{N})$. Nonetheless, numerous shades of the given colours can appear, therefore the development of a quantitative standard may be an important step for the market, due to the fact that the berry skin colour primarily affects the consumers' choice (Cliff et al., 1996; Rolle et al., 2011; Zeppa et al., 1999).

There are numerous dimensions measuring colour, for example XYZ, Yxy, CMY, CIE $\mathrm{L}^{*} \mathrm{a} \mathrm{b}^{*}$, CIE L*a*v*. L*a*b* (lightness, red/green and yellow/blue chromaticity coordinate) can be measured by different spectrophotometers, such as the ColorLite sph850 spectrophotometer (ColorLite GmbH, Katlenburg-Lindau, Germany), which measures the colour of solid material based on reflection, while the colour of liquids based on transmission. This device was applied in many studies to evaluate colour of agricultural products, such as pepper (Baranyai et al., 2011), citrus (Goulas and Manganaris, 2012), orange (Garnacho et al., 2012) and apricot (Firtha et al., 2010).

Grapevine, as most fruits and vegetables, is usually stored from the harvest until selling, and in most of the cases its transport takes a longer time. According to the literature, the optimal storage condition for table grapes is $-1-0{ }^{\circ} \mathrm{C}$, this low temperature prevents for example water loss (Gross et al., 2016). In addition, consumers store them further until consumption. Consequently, the effect of storage is a significant factor. According to Chironi et al. (2017), long-term cold storage has an effect on the different attributes of table grapes such as general appearance, colour, turgidity, consistency, crispness and so on and so forth.

The aim of this experiment was to evaluate the colour of different grapevine accessions (table and wine grapes) influenced by the length of cold storage.

\section{MATERIALS AND METHODS}

Berry samples were collected in the Research Institute for Viticulture and Oenology of the National Agricultural Research and Innovation Centre (Kecskemét, Hungary). Grapevine accessions Agaphante, KM98, Roter Velteliner, Korona, Pinot gris, Pozsonyi, Ros de Minis, Traminer, T9, Zenit were investigated. Among these the following accessions are wine grapes: 'Roter Velteliner', 'Pinot gris', 'Pozsonyi', 'Traminer', 'Zenit'. Accessions were chosen to obtain a wide palette of different berry colours. Bunches were harvested in 2019 in full ripeness. Thirty berries of each accessions were collected randomly of the middle part from several bunches and stored in plastic boxes until the colour measurements. Measurements were carried out 4 times with 1 -week intervals. The same 30 berries were measured on each occassion. Between the measurements the samples were stored at $6 \pm 0.3{ }^{\circ} \mathrm{C}$ degrees in $28.2 \pm 0.7 \% \mathrm{RH}$ refrigerator, the conditions were verified by a VOLTCRAFT DL-120 (Conrad, Germany) temperature and relative humidity data logger. Colour of the berries was measured by a ColorLite sph850 spectrophotometer (Fig. 1). The spectrophotometer was calibrated by two etalons, a BAM white ceramic etalon and a white acryl etalon. Three repetitions were carried out with each berry in every week to minimize noise. The final $\mathrm{L}^{*} \mathrm{a} \mathrm{b}^{*}$ values were the average of the three repetitions per berry.

The effect of the storage on the colour was also investigated based on the colour index (CI) calculated by the $\mathrm{L}^{*} \mathrm{a}^{*} \mathrm{~b}^{*}$ values $\left(100 \times \mathrm{a}^{*} / \mathrm{L}^{*} \times \mathrm{B}^{*}\right)$ (Goulas and Manganaris, 2012). CI was calculated by the $L^{*} a^{*} b^{*}$ values; this is the reason why negative CI values are present while $\mathrm{L}^{*} \mathrm{a} \mathrm{b}^{*}$ are all positive. Furthermore, the changes of the $\mathrm{L}^{*} \mathrm{a} \mathrm{b}^{*}$ values were investigated by 


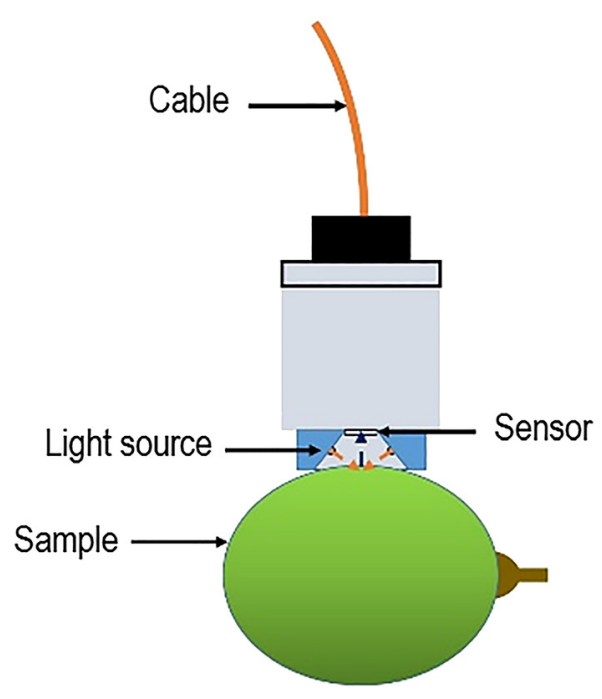

Fig. 1. Illustration of the probe head of ColorLite sph 850 (according to: www.colorlite.de)

analysis of variance (ANOVA), Dunn's post hoc test, which were carried out in the PAST 3.12 (Hammer et al., 2001).

\section{RESULTS}

Analysis of the $\mathrm{L}^{*} \mathrm{a}^{*} \mathrm{~b}^{*}$ values individually and colour index $\left(100 \times \mathrm{a}^{*} /\left(\mathrm{L}^{*} \times \mathrm{B}^{*}\right)\right)$ was investigated. Results showed that $\mathrm{L}^{*}$ is the most sensitive to the length of the cold storage. According to the ANOVA the value of all accessions significantly changed $(P \leq 0.05)$. In some cases, (KM98) the value decreased only after the 3rd week of storage, in other cases (Pinot gris) the change started after the 1st week of storage. The values of $\mathrm{a}^{*}$ were the less variable among the tree colour components. For example, in the case of Pinot gris, Ros de Minis, Pozsonyi, Korai piros veltelini and Traminer the values were not changing. The length of the cold storage influenced significantly the value of $b^{*}$. The change was detectable for all genotypes except KM98 and Korona. Significant difference of all the 3 values was observed in the case of T9, Zenit and Agaphante. Results showed that in the case of KM98, Ros de Minis, Zenit, Pozsonyi, Korai piros veltelini, Agaphante and Traminer the cold storage had no effect on the colour index. The colour index significantly changed only in some cases (Pinot gris, T9, Korona) caused by the length of the storage. The accession T9 showed the highest sensitivity among all and all values were significantly changed during the storage (Table 1).

\section{DISCUSSION}

Colour is one of the most important characteristics of foods, especially of fruits and vegetables (Barrett et al., 2010). In most of the cases long-term storage is necessary for the fruits and vegetables to get from the field to the market, and consumers also store the purchased crops in 
Table 1. Mean L*a*b* colour values and CI colour index of different grapevine genotypes influenced by the length of the cold storage

\begin{tabular}{|c|c|c|c|c|c|}
\hline Cultivar & Week after harvest & $\mathrm{L}^{*}$ & $a^{*}$ & $\mathrm{~b}^{*}$ & $\mathrm{CI}$ \\
\hline \multirow[t]{4}{*}{ KM98 } & 1 & $25.59^{b} \pm 0.00$ & $3.16^{\mathrm{a}} \pm 1.13$ & $0.18 \pm 1.14$ & $-52.38 \pm 263.75$ \\
\hline & 2 & $25.39^{\mathrm{b}} \pm 1.90$ & $4.07^{\mathrm{b}} \pm 1.13$ & $-0.18 \pm 1.30$ & $-11.09 \pm 58.51$ \\
\hline & 3 & $26.06^{\mathrm{b}} \pm 1.34$ & $3.43^{\mathrm{a}} \pm 1.20$ & $0.07 \pm 1.36$ & $4.23 \pm 35.54$ \\
\hline & 4 & $23.45^{\mathrm{a}} \pm 1.92$ & $3.55^{\mathrm{ab}} \pm 1.05$ & $0.15 \pm 1.46$ & $7.15 \pm 86.91$ \\
\hline \multirow[t]{4}{*}{ Pinot gris } & 1 & $19.76^{\mathrm{c}} \pm 3.69$ & $2.3 \pm 0.91$ & $-1.18^{\mathrm{a}} \pm 0.97$ & $-20.23^{\mathrm{a}} \pm 74.94$ \\
\hline & 2 & $15.08^{\mathrm{a}} \pm 2.19$ & $2.54 \pm 1.29$ & $0.36^{\mathrm{b}} \pm 0.94$ & $11.27^{\mathrm{b}} \pm 150.13$ \\
\hline & 3 & $15.3^{\mathrm{a}} \pm 2.01$ & $2.79 \pm 1.33$ & $1.23^{c} \pm 0.94$ & $17.82^{\mathrm{b}} \pm 12.54$ \\
\hline & 4 & $16.84^{\mathrm{b}} \pm 1.98$ & $2.32 \pm 1.08$ & $0.66^{\mathrm{bc}} \pm 0.84$ & $58.33^{b} \pm 338.91$ \\
\hline \multirow[t]{3}{*}{ Ros de Minis } & 1 & $26.18^{c} \pm 2.40$ & $1.66 \pm 1.33$ & $3.3^{\mathrm{a}} \pm 1.98$ & $1.13 \pm 19.01$ \\
\hline & 2 & $22.93^{\mathrm{a}} \pm 2.15$ & $2.09 \pm 1.53$ & $4.23^{\mathrm{a}} \pm 1.69$ & $3.06 \pm 2.80$ \\
\hline & 3 & $24.09^{b} \pm 2.09$ & $1.91 \pm 0.99$ & $5.38^{\mathrm{b}} \pm 1.46$ & $1.72 \pm 1.23$ \\
\hline \multirow[t]{4}{*}{ T9 } & 1 & $21.32^{c} \pm 2.64$ & $-0.14^{\mathrm{a}} \pm 0.40$ & $-3.65^{\mathrm{a}} \pm 0.91$ & $0.13^{\mathrm{a}} \pm 0.71$ \\
\hline & 2 & $19.56^{\mathrm{b}} \pm 2.47$ & $-0.76^{\mathrm{a}} \pm 3.42$ & $-2.65^{b} \pm 1.06$ & $2.33^{\mathrm{a}} \pm 10.75$ \\
\hline & 3 & $16.92^{\mathrm{a}} \pm 2.12$ & $-0.03^{b} \pm 0.21$ & $-2.84^{\mathrm{b}} \pm 1.08$ & $0.1^{\mathrm{a}} \pm 0.57$ \\
\hline & 4 & $20.64^{c} \pm 1.22$ & $-0.36^{\mathrm{c}} \pm 0.22$ & $-1.85^{\mathrm{c}} \pm 1.09$ & $2.13^{b} \pm 3.71$ \\
\hline \multirow[t]{3}{*}{ Zenit } & 1 & $24.05^{c} \pm 1.63$ & $0.58^{\mathrm{a}} \pm 0.79$ & $6.5^{\mathrm{a}} \pm 1.40$ & $0.35 \pm 0.52$ \\
\hline & 2 & $21.38^{\mathrm{a}} \pm 1.11$ & $0.73^{\mathrm{ab}} \pm 0.74$ & $8.49^{b} \pm 1.43$ & $0.38 \pm 0.42$ \\
\hline & 3 & $22.65^{b} \pm 1.88$ & $1.11 \pm 0.90^{\mathrm{a}}$ & $8.48^{\mathrm{b}} \pm 1.36$ & $0.56 \pm 0.45$ \\
\hline \multirow[t]{4}{*}{ Pozsonyi } & 1 & $23.96^{\mathrm{b}} \pm 2.11$ & $2.66 \pm 1.58$ & $2.07^{\mathrm{a}} \pm 1.84$ & $-3.95 \pm 59.4$ \\
\hline & 2 & $22.19^{\mathrm{a}} \pm 1.73$ & $3.21 \pm 1.32$ & $1.88^{\mathrm{ab}} \pm 1.93$ & $10.28 \pm 49.48$ \\
\hline & 3 & $21.41 \pm 2.38^{\mathrm{a}}$ & $3.31 \pm 1.38$ & $2.84^{b c} \pm 2.00$ & $4.57 \pm 19.15$ \\
\hline & 4 & $21.38 \pm 1.91^{\mathrm{a}}$ & $2.68 \pm 1.46$ & $3.32^{\mathrm{c}} \pm 2.43$ & $5.74 \pm 7.90$ \\
\hline \multirow[t]{3}{*}{ K.p. veltelini } & 1 & $23.07 \pm 2.62^{b}$ & $1.24 \pm 0.98$ & $5.06^{\mathrm{a}} \pm 2.28$ & $1.06 \pm 0.69$ \\
\hline & 2 & $21.85 \pm 2.7^{\mathrm{ab}}$ & $1.02 \pm 0.76$ & $5.17^{\mathrm{a}} \pm 1.64$ & $0.96 \pm 0.71$ \\
\hline & 3 & $21.02^{\mathrm{a}} \pm 1.51$ & $1.28 \pm 0.98$ & $6.55^{\mathrm{b}} \pm 1.63$ & $0.98 \pm 0.77$ \\
\hline \multirow[t]{4}{*}{ Agaphante } & 1 & $22.22^{c} \pm 2.05$ & $4.85^{\mathrm{b}} \pm 0.89$ & $-1.45^{\mathrm{a}} \pm 1.37$ & $-22.23 \pm 78.15$ \\
\hline & 2 & $20.5^{b} \pm 2.50$ & $4.16^{\mathrm{a}} \pm 1.00$ & $-0.86^{\mathrm{ab}} \pm 1.47$ & $22.99 \pm 252.28$ \\
\hline & 3 & $20.99^{b c} \pm 2.27$ & $3.97^{\mathrm{a}} \pm 0.93$ & $-0.51^{\mathrm{b}} \pm 1.01$ & $19.79 \pm 547.58$ \\
\hline & 4 & $19.9^{\mathrm{a}} \pm 2.10$ & $4.14^{\mathrm{a}} \pm 0.89$ & $-0.29^{\mathrm{b}} \pm 0.84$ & $-2.24 \pm 74.69$ \\
\hline \multirow[t]{3}{*}{ Korona } & 1 & $25.62^{b} \pm 1.53$ & $-0.03^{\mathrm{a}} \pm 0.81$ & $8.98 \pm 1.75$ & $-0.04^{\mathrm{a}} \pm 0.35$ \\
\hline & 2 & $24.58^{\mathrm{a}} \pm 1.77$ & $0.12^{\mathrm{a}} \pm 0.89$ & $10.13 \pm 2.14$ & $0.03^{\mathrm{a}} \pm 0.33$ \\
\hline & 3 & $24.85^{\mathrm{ab}} \pm 1.75$ & $0.91^{b} \pm 1.06$ & $9.87 \pm 2.41$ & $0.36^{\mathrm{b}} \pm 0.40$ \\
\hline \multirow[t]{3}{*}{ Traminer } & 1 & $22.28^{\mathrm{b}} \pm 2.47$ & $3.4 \pm 1.38$ & $2.87^{\mathrm{a}} \pm 1.82$ & $-0.26 \pm 48.83$ \\
\hline & 2 & $20.71^{b} \pm 3.25$ & $3.68 \pm 1.67$ & $4.2^{\mathrm{b}} \pm 1.95$ & $5.37 \pm 3.79$ \\
\hline & 3 & $20.44^{\mathrm{a}} \pm 2.28$ & $4.15 \pm 1.46$ & $5^{b} \pm 1.90$ & $4.79 \pm 2.94$ \\
\hline
\end{tabular}

*Different letters within the same column mean significant differences in the colour values of each genotypes caused by length the cold storage according to Dunn's post hoc test $(P \leq 0.05)$.

the refrigerator for a couple of days. Several studies were dedicate to this topic. According to Ozturk et al. (2012), the colour characteristics of plum change during cold storage. According to Ma et al. (2016), home storage of the table grape is an important part of the supply chain, therefore, the performance of the fruit during the time before consumption is necessary to be investigated. In their study Chironi et al. (2017) investigated the change of cluster colour uniformity and berry colour uniformity of Italia and Red globe grapevine cultivars and found that those are changing during the storage. In this study the colour of 10 grapevine accessions' berries were evaluated during long term cold-storage. Colour value $\mathrm{L}^{*}$ was the most variable among the 3 dimensions, it showed the most changes all along the surveillance All cultivars showed change in this dimension caused by the cold storage. Colour value $b^{*}$ was changed only in the case of a few cultivars (KM9, Korona). Colour index (100a*/L*b*) introduced in Goulas and Manganaris (2012) was investigated. The negative value of this variable refers to greenish, while the positive values to reddish tonalities of the samples. According to the analysis of variance of the colour index $\left(100 \mathrm{a}^{*} /\left(\mathrm{L}^{*} \mathrm{~b}^{*}\right)\right)$ most of the accessions showed significant difference. In the case of T9 all 
variables were significantly changed during the cold storage. In most cases the values were negative during the $1^{\text {st }}$ measurements (KM98, Pinot gris, Pozsonyi, Agaphante, Korona and Traminer) and turned to positive values during the cold storage in all cases. Condition of the accessions was also variable. In the case of Ros de Minis, Korai piros veltelini, Korona, Traminer after the third week samples lost the quality and it was not possible to repeat the measurements. According to some researches of drying grapes, the colour changes may occur due to the water loss of the cells, which colour change could be considered as browning (Bingol at al., 2012).

\section{CONCLUSION}

Our results showed that berry colour of the grapevine significantly changes during the cold storage and this change is not uniform among the cultivars.

\section{ACKNOWLEDGEMENT}

Supported by the ÚNKP-19-3-1 New National Excellence Program of the Ministry for Innovation and Technology.

\section{REFERENCES}

Baranyai, L., Dénes, L.D., Papucsek, G., and Felföldi, J. (2011). Evaluation of color development pattern on pepper (Capsicum annuum) surface In: Chinese-European cooperation for a long-term sustainability. Magyarország, Budapest, 2011.11.10-2011.11.11. Paper Paper S3/1.

Barrett, D.M., Beaulieu, J.C., and Shewfelt, R. (2010). Color, flavor, texture, and nutritional quality of freshcut fruits and vegetables: desirable levels, instrumental and sensory measurement, and the effects of processing. Critical Reviews In Food Science and Nutrition, 50(5): 369-389, https://doi.org/10.1080/ 10408391003626322.

Bényei, F. and Lőrincz, A. (2005). Borszöloofajták, csemegeszölöfajták és alanyok. Mezőgazda Kiadó. Budapest, p. 314.

Bingol, G., Roberts, J.S., Balaban, M.O., and Devres, Y.O. (2012). Effect of dipping temperature and dipping time on drying rate and color change of grapes. Drying Technology, 30: 597-606.

Chironi, S., Sortino, G., Allegra, A., Saletta, F., Caviglia, V., and Ingrassia, M. (2017). Consumer assessment on sensory attributes of fresh table grapes cv "Italia" and "Red Globe" after long cold storage treatment. Chemical Engineering Transactions, 58: 421-426, https://doi.org/10.3303/CET1758071.

Cliff, M.A., Dever, M.C., and Reynolds, A.G. (1996). Descriptive profiling of new and commercial British Columbia table grape cultivars. American Journal of Enology and Viticulture, 47(3): 301-308.

Cliff, M., Sanford, W., Wisner, W., and Hampson, C. (2002). Use of digital images for evaluation of factors responsible for visual preference of apples by consumers. HortScience, 37(7): 1127-1131.

Crisosto, C.H., Crisosto, G.M., and Metheney, P. (2003). Consumer acceptance of 'Brooks' and 'Bing' cherries is mainly dependent on fruit SSC and visual skin color. Postharvest Biology and Technology, 28: 159-167. 
Csepregi P. and Zilai Z. (1955). Szőlőfajtáink. Ampelográfia. Mezőgazdasági Kiadó, Budapest, p. 386.

De Groote, H. and Kimenju, S.C. (2008). Comparing consumer preferences for color and nutritional quality in maize:Application of a semi-double-bound logistic model on urban consumers in Kenya. Food Policy, 33: 362-370.

Firtha, F., Kaszab, T., Lambert-Meretei, A., and Felföldi, J. (2010). Predicting ingredients and physical properties of apricot using multispectral imaging. Journal of Agricultural and Food Chemistry, 53: 10034-10041.

Frank, C.A., Robert, G.N., Eric, H.S., Bridget, K.B., and Amarat, H.S. (2001). Consumer preferences for color, price, and vitamin C content of bell peppers. HortScience, 36(4): 795-800.

Garnacho, G., Kaszab, T., Horváth, M., and Géczi, G. (2012). Comparative study of heat-treated orange juice. Journal of Microbiology, Biotechnology and Food Sciences, 2(2): 446-457.

Goulas, V. and Manganaris, G.A. (2012). Exploring the phytochemical content and the antioxidant potential of Citrus fruits grown in Cyprus. Food Chemistry, 131: 39-47.

Gross, K.C., Wang, C.Y., and Saltveit, M. (2016). The commercial storage of fruits, vegetables, and florist and nursery stocks. Agriculture Handbook 66, U.S. Department of Agriculture, Agricultural Research Service, Washington, DC.

Hamadziripi, E.T., Theron K.I., Muller, M., and Steyn, J.W. (2014). Apple compositional and peel colo differences resulting from canopy microclimate affect consumer preference for eating quality and appearance. HortScience, 49(3): 384-392.

Hammer, O., Harper, D.A.T., and Ryan, P.D. (2001). PAST: Paleontological Statistics software package for education and data analysis. Paleontologia Electronica, 4(1): 9.

Ismail, B., Djendoubi, N., Kodia, A., Ben Hassine, D., and Ben Slama, M. (2013). Physicochemical characterization and sensory profile of 7 principal Tunisiandate cultivars. Emirates Journal of Food and Agriculture, 25(5): 331-341, https://doi.org/10.9755/ejfa.v25i5.12396.

Jemison J.M., Sexton P., and Camire M.E. (2008). Factors influencing consumer preference of fresh potato varieties in Maine. American Journal of Potato Research, 85: 140-149, https://doi.org/10.1007/s12230008-9017-3.

Kelley, K.M., Behe, B.K., Biernbaum, J.A., and Poff, K.L. (2001). Consumer preference for edible flower color, container size, and price. HortScience, 36(4): 801-804.

Kozma, P. (1968). Csemegeszóló. Mezőgazda Kiadó, Budapest, p. 451.

Liao, H., Cai, Y., and Haslam, E. (1992). Polyphenols interactions. Anthocyanins: copigmentation and color changes in red wines. Journal of the Science of Food and Agriculture, 59: 299-305.

López Camelo, A.F. and Gómez, P.A. (2004). Comparison of color indexes for tomato ripening. Horticultura Brasileira, Brasília, 22(3): 534-537.

Ma, C., Fu, Z., Xu, M., Trebar, M., and Zhang, X. (2016). Evaluation on home storage performance of table grape based on sensory quality and consumers' satisfaction. Journal of Food Science and Technology, 53 (3): 1363-1370.

Mazza, G., Fukumoto,L., Delaquis, P., Girard, B., and Ewert, B. (1999). Anthocyanins, phenolics, and color of Cabernet Franc, Merlot, and Pinot noir wines from British Columbia. Journal of Agricultural and Food Chemistry, 47: 4009-4017.

Mendes-Pinto, M.M., Ferreira, C.A., Caris-Veyrat, C., and De Pinho, P.G. (2005): Carotenoid, chlorophyll, and chlorophyll-derived compounds in grapes and Port wines. Journal of Agricultural and Food Chemistry, 53(26):10034-10041.

OIV. (2009). OIV descriptor list for grape varieties and Vitis species, 2nd ed. Office International de la Vigne et du Vin, Paris, France. 
Ozturk, B., Kucuker, E., Karaman, S., and Ozkan, Y., 2012. The effect of cold storage and aminoethoxyvinylglycine (AVG) on bioactive compounds of plum (Prunus salicina Lindell cv. 'Black Amber'). Postharvest Biology and Technology, 72: 35-41.

Rolle, L., Giacosa, S., Gerbi, V., and Novello, V. (2011). Comparative study of texture properties, color characteristics, and chemical composition of ten white table grape varieties. American Journal of Enology and Viticulture, 62: 49-56.

Zeppa, G., Rolle, L., and Gerbi, V. (1999). Use of consumer test for the sensory evaluation of a red grape. Industrie Alimentari, 38(383): 818-824.

Open Access. This is an open-access article distributed under the terms of the Creative Commons Attribution 4.0 International License (https://creativecommons.org/licenses/by/4.0/), which permits unrestricted use, distribution, and reproduction in any medium, provided the original author and source are credited, a link to the CC License is provided, and changes - if any - are indicated. (SID_1) 